\title{
Separation of Powers in Pre-modern Western Political Thought and the Building of the State of Law in Vietnam
}

\author{
Lai Quoc Khanh
}

Among the signs of a state of law, there is one that is widely recognized by researchers in the world, which is that the power of the government is operated according to the principle of separation of powers as an internal control method to avoid the abuse/manipulation of power. In the organization of governing systems in many countries, the separation of powers principle has been applied in different ways. The birth of the separation of powers principle and the fact that this concept is used widely in the political life of humankind is a proof of its value.

The Constitution of the Socialist Republic of Vietnam (amended in 2013) ${ }^{1}$ states that the Vietnamese state is a socialist state of law, of the people, by the people and for the people. All the power of the state belongs to the people based on the alliance between the working class, the peasantry and the intellectuals. State power is united, and at the same time is entrusted to state agencies that collaborate with and monitor one another in the implementation of legislative, executive and judicial powers. Thus, technically, the Vietnamese state is not constructed based on the separation of powers principle. Nevertheless, it cannot be denied that the useful values of the separation of powers principle have been applied in organizing and exercising Vietnamese state power, thereby establishing the principle of "division, collaboration and mutual monitor-

\footnotetext{
${ }^{1}$ From now on Constitution of Vietnam.
} 
ing amongst state agencies in implementing legislative, executive and judicial powers." This is a new point, a step forward in Vietnamese political and constitutional thinking, which overcomes the old thinking that rigidly regards the separation of powers principle as a distinctive feature of Western capitalistruled states.

In order to understand the values underlying the separation of powers principle, and through which to understand more clearly the values of the Vietnamese constitution (2013) and utilize these values more in the future, we started to research the separation of powers principle in pre-modern Western political thought by studying three representatives: John Locke, Charles-Louis de Secondat de Montesquieu and Jean-Jacques Rousseau.

During the Dark Middle Age, the progressive political thoughts that were established in the period of Ancient Greece including the separation of powers principle associated with the reputation of thinkers such as Solon (c. 638-558 B.C.), Cleisthenes (c. 570-508 B.C.), Ephialtes ( ${ }^{\text {th }}$ century B.C.), Pericles (495-429 B.C.), etc., and especially Aristotle (384-322 B.C.), re-emerged and developed together with the establishment of the pre-modern mode of capitalist production and became ideological guidelines for Western European bourgeois revolutions. The separation of powers principle has been developed and improved by outstanding thinkers namely John Locke, Charles-Louis de Secondat de Montesquieu, and Jean-Jacques Rousseau and has become the theory underlying the organization and building of modern states.

\section{Locke's Thoughts on the Separation of Powers}

John Locke (1632-1704) is the author of a series of classic works in the history of philosophical and political thoughts of humankind such as "An Essay concerning Humane Understanding”, "Two Treatises of Government”, “A Letter Concerning Toleration", "Some Thoughts Concerning Education”, etc.

If "The First Treatise of Government" was written with the purpose of criticizing the patriarchal perspective on government of authors at the time, then the "Second Treatise of Government" is the work by which Locke developed his view about the state. In this writing, Locke's thinking on the separation of powers was strongly expressed. Locke claimed that in a republic state there are three main types of powers: legislative, executive and federative. In these three 
types, the legislative power is the first and basic power of every nation state, so the legislative body holds supreme power. Locke wrote: "The legislative body holds not only the supreme power of a nation community, but also the sacred and non-transferable power once the community puts it into that position." The law is only effective, supreme, and forces all members to follow it once it is approved by the legislative body. The "recognition" of the legislative body represents the "recognition" of the society. However, originating from the popular thoughts at his time, i.e. the thoughts on natural rights and the social contract, Locke pointed out that, as an authorized body, the legislative body is bound by the following principles:

- It does not and cannot hold arbitrary power, meaning that its power cannot be higher than that of the subject that has granted power to it - the citizens. In other words the "natural rights" that human beings receive when joining the community is the supreme power that controls everybody, including the legislators.

- The legislative agency has to act properly according to rules that are "transparent and approved" which reflect human beings' natural rights.

- These transparent and approved rules have to protect people's rights, especially property rights.

- The legislative body cannot transfer the power of law-making to anybody else because it is power assigned by the citizens.

However, because laws "can be made in a short period of time, it is unnecessary for the legislative agency to be present and to have tasks to perform at all times." Simultaneously, to avoid the trend that legislators "monopolize power" to serve personal purposes, legislative power "has to be assigned to many people gathering at the right time (...) Upon finishing that duty, they will dismiss and themselves will be subject to the laws that they make." ${ }^{4}$ In order to satisfy the demand of enforcing the law in the long run, "there must be a power that always is present to observe the enforcement of already-made laws by means of violence", so legislative and executive power have to be separated, and the executive body has to be present at all times.

\footnotetext{
${ }^{2}$ Locke (2007), 183.

${ }^{3}$ Locke (2007), 199.

${ }^{4}$ Locke (2007), 200
} 
Beside legislative and executive powers, there is another power that can be considered natural, said Locke, which is federative power. Federative power means "the right to war and peace, to form union and alliance, to make other agreements, with individuals and communities outside the national community." Executive and federative powers have to be distinctive; however they still have a close connection because they both "need the force of the society to be enforced." 6

Not only contributing to specifying the factors that constitute state power, the distinction between key types of state power as well as the allocation of these powers to different official authorities, Locke also thoroughly discussed the relationship between the types of power and these agencies. Locke always argued that supreme power belongs to the people. At first, this point is true in the case of the organization with the supreme power, the legislative body. He wrote: "among the people lies a supreme power to terminate or change the legislative body, when they realize that the legislative body acts in ways that run counter to its assigned missions." This is the "supreme power" of the people to "save themselves" when the authorized organization plots and acts in ways detrimental to their benefit. Regarding the relationship between the legislative and executive bodies, Locked argued that the legislative body holds the supreme state power, and other powers, held by any member or group in the society, have to originate from it and depend on it.

Executive and federative powers have to depend on legislative power. According to Locke, executive power cannot be put elsewhere rather than on a person that is also a member of the legislative body (the king), and because the legislative body assigns the right to implement laws that they make to executive officials, they still have the power to take it back if they see a reason to do so, even to punish any weak operation that contradicts the law. The same principle applies to federative power. The right to assemble and perform their activities are set by the constitution. They themselves have the power to postpone meetings and their own activities. Although dependent, executive power is independent in some way and can also influence legislative power. This influence is manifested through the mechanism of summoning and dissolving

\footnotetext{
${ }^{5}$ Locke (2007), 201.

${ }^{6}$ Locke (2007), 202.

${ }^{7}$ Locke (2007), 203.
} 
the legislative body. Locke put the right to summon and dissolve the legislative body beyond constitutionally stipulated meetings into the hand of the legislative body, in situations when there is a need to hold a new election between two constitutionally stipulated meetings, when emergency cases of the society require amendments of existing laws or the issuance of new laws, etc. The act of assigning the power to assemble and dissolve the legislative body to the executive body is also a form of authorization by citizens. If legislators use this power to hinder legitimate activities this is a declaration of war against the people, and the people will use their supreme power to take back all the state's power, even by means of violence. The executive body also has another power over the legislative agency, which is the power to decide the number of representatives of the people in different regions and their privileges of action. Privileges of action as well as other rights of the executive body all originate from the principle of "Salus populi suprema lex" (the happiness of the people is the supreme power), and is very necessary because in reality, there are things that the law cannot or should not prescribe, and also due to the inability of the legislative body to be always present, as well as the "delay" of legislative activities in comparison with the rapid pace of social life. In order to prevent the privileges of action from doing harm to the people, it is necessary to understand that this is the power assigned by the people to executive officials, and therefore the citizens have the right to limit it, and executives cannot have so many privileges of action anyhow.

Therefore, it can be seen that Locke has made immense progress in the thinking about the separation of powers. His opinion of the division of power, the interdependence of different types of power and state agencies as mentioned above is the profoundly practical materialization of simple ideas about the separation of powers since the period of ancient Greece. The most special point in Locke's thought on the separation of powers is that he is consistent in the idea that the supreme power should always belong to the people, and all the methods to govern and operate state apparatuses are to be aimed at guaranteeing the people's benefit. However, it is obvious that Locke faced a difficulty in answering a practical question that he himself created: Who will judge whether an authorized power is used properly? His answer is that the people cannot find a secular judge and thus they have to "pray to heaven". This opinion expresses the incompleteness of Locke's thought on the separation of pow- 
ers as he did not give enough attention to judicial power and "secular" judicial organizations.

\section{Montesquieu's Thoughts on the Separation of Powers}

Charles de Secondat Montesquieu (1689-1755) wrote a number of works including the three most popular ones namely "Persian Letters", "Considerations on the Causes of the Greatness of the Romans and their Decline" and "The Spirit of the Laws". The writing that made him one of the most preeminent political thinkers of humankind - "The Spirit of the Laws" - was published in 1784 , after 20 years of diligent research as its author admitted. Setting up the research topic as "the spirit of the laws", Montesquieu proposed an opinion that the existence of the law is indispensable and universal:

"The law, in the broadest meaning, is indispensable relationships that are inherent in the nature of things or events. According to this meaning, everything has its own laws."

Therefore, humankind has its own laws. He argued that, humankind has two main kinds of law, political and civil. "In a society, in order to maintain discipline, it is necessary to point out the relationship between the administrator and the administered. That is political law. The regulation of relationships between citizens is civil law." Political and civil laws, according to Montesquieu, are the particular application of "human reasoning" in specific cases. Political laws create a governing system, and civil laws help maintaining it. Nevertheless, the reason for the existence of both political and civil laws is to guarantee people's political freedom. Montesquieu wrote:

"Political freedom (...) only exists if there is no abuse of power. However, the experience of all times point out that, those who are granted power tend to abuse that power and seek to maximize that power for their own use (...) In order to avoid this behavior, a natural necessity is that power has to be controlled by power. One government like that can be established if no one is forced to do things that the law does not oblige him to do, and no one is prevented from doing things that the law permits" 10

\footnotetext{
${ }^{8}$ Montesquieu (1996), 39.

${ }^{9}$ Montesquieu (1996), 44.

${ }^{10}$ Montesquieu (1996), 75.
} 
This is a really important quote from Montesquieu because it shows that he is more progressive than Locke and preceding thinkers on the separation of powers. It was not until Montesquieu's opinion that the core of the separation of powers principle, i.e. "power has to be hindered by power," was established. Before him, the main focus was just on the allocation of political power to different state organizations and the relationship between the powers and these organizations, without showing the nature of that relationship.

Discussing the types of state power, Montesquieu stated that in each nation there are three types of power: "Legislative power, executive power to implement rules that are compatible with international laws and executive power to implement civil law." $\mathrm{He}$ explained further that the second type is "national executive power" and the third one is "judicial power". ${ }^{12}$ It can be seen that Montesquieu clearly defined the division of political power into three types that are legislative power, executive power and judicial power. This is one of his contributions.

Montesquieu affirms clearly that the three types of power above have to be assigned to different governing organizations of the state. It is because:

"When legislative and executive powers are both assigned to one person or one Senate, there is no such thing as freedom; because there is a danger that the person himself or the Senate itself issues authoritarian laws to implement in an authoritarian way. There is no such thing as freedom if judicial power is not separated from legislative and executive powers. If judicial and legislative powers join together, the holder of these powers will dictate the right to live and freedom of the citizens; the judge will issue laws. If judicial power and executive power join together, the judge will have the power of a suppressor. If one person or an organization of officials or of aristocrats, or of the people holds all the above powers, then everything will vanish." ${ }^{13}$

Montesquieu took the examples of European, Turkish and Italian politics to justify the above opinion. His general comment after comparing those regimes was: If the three types of power join together, this will lead to autocracy.

Regarding judicial power, Montesquieu stated that it should not be assigned to a permanent senate, "but it should be assigned to the people elected by the citizens each time in a year, prescribed by laws, who set up a court and

\footnotetext{
${ }^{11}$ Montesquieu (1996), 100.

${ }^{12}$ Montesquieu (1996), 100.

${ }^{13}$ Montesquieu (1996), 100-101.
} 
work as long as required." ${ }^{14}$ In this way, the judges have the same position as the accused, so the accused will not think that he is in the hands of those that are able and willing to do harm to him. The purpose of the above mechanism is to reduce the permanent fear of the people towards judging power. Thus, Montesquieu held that judging power should not be assigned to an organization or a fixed position, but a judging "mechanism" should be created. Additionally, when the accused have a dispute with the law, they have to be able to choose their judges, or to decline the assigned judges. However, to avoid another extreme as well as to avoid rendering the people helpless before judging mechanisms, Montesquieu thought that the court should not be fixed, but sentences should be recorded, and laws should contain only particular articles (legal precedents).

About legislative and executive powers, Montesquieu argued that it is possible to "assign these types of power to permanent organizations and officials, because these powers should not be given to an individual. Legislative power expresses the collective will of a nation and executive power exercises that collective will." 15

With the idea of a free state as a state where citizens control themselves, Montesquieu stated that the people "must have legislative power" and implementi this power by "assigning to the representatives all the tasks that individuals cannot do by themselves." 16 This idea shows that Montesquieu already paid attention to the techniques of legislative work rather than only discussing abstract democratic notions. He considered that the people are the supreme holder of power, but within political work, not every task can be done by everyone. According to Montesquieu, the people's representatives have to be elected by regions, not the whole country. The function of the legislative body is not solving particular problems, but "creating laws, and considering how these laws are implemented." ${ }^{17}$ As to the structure of the legislative body, Montesquieu proposed a model with two sections: one includes representatives of aristocrats (Senate) and the other consists of people's representatives (House).

\footnotetext{
${ }^{14}$ Montesquieu (1996), 102.

${ }^{15}$ Montesquieu (1996), 102-103.

${ }^{16}$ Montesquieu (1996), 104.

${ }^{17}$ Montesquieu (1996), 105.
} 
In order for the senate not to fall into the habit of focusing on their own interests without considering the people's will, he thought that there should be a supreme law stating that the senate should only have the function of preventing, not the function of making rules and regulations. According to Montesquieu, executive power should be assigned to a king, because executive power always requires immediate actions which should be conducted by one person rather than many.

Highlighting the importance of the separation of powers, Montesquieu opposed the idea that executive power should belong to some members or the whole parliament. He also agreed with Locke that the executive body should have the right to summon or set the date and time of parliamentary meetings. Moreover, the executive body also has the right to prevent the legislative body's plans, in order to reduce the risk that the legislative body becomes autocratic. Obviously, the executive body has limited power, which means it can only solve temporary issues and cannot be involved in legislative work, "cannot argue about works", "cannot propose petitions”. The legislative body, although it does not hold the power of preventing executive power and judging executive officials, has the right to "consider how established laws have been implemented", which, in modern parlance, means it has supervisory power. Judicial power should not combine with any part of legislative power, but with three exceptions:

- Aristocrats are judged by a legislative body including aristocrats only, because "big men are often objects of envy".

- Laws are mechanical, sometimes even blind and severe; therefore the aristocrats in the legislative body should use their power, for the laws' benefit, to reduce the harshness when issuing a sentence.

- In order to prevent aristocrats from covering for each other, the people's legislative body has the right to report to the aristocrats in the legislative body.

State power is associated with violent instruments, thus in order to protect the people from being repressed, Montesquieu proposed that the army had to be close to the people and dependent on the executive body, not the legislative one.

Thus, after examining some basic opinions of Montesquieu about organizational forms and operational methods of state apparatuses, we can say that he made a great contribution to the establishment of the separation of powers 
principle. Montesquieu's thoughts on the separation of powers not only inherited but also developed previously incomplete ideas about the separation of powers. Furthermore, because he focused on summarizing practical experience and at the same time was influenced by experimental methods, Montesquieu's thoughts on the separation of powers are profoundly practical and have great potential to be applied.

\section{Rousseau's Thoughts on the Separation of Powers}

The writing that expresses Jean-Jacques Rousseau's (1712-1778) distinctive thoughts on the separation of powers and other political ideas is "The Social Contract, or Principles of Political Right", published in 1762. "The Social Contract" serves the purpose of "looking in the civil order to see whether there is any strong, reasonable rule that can treat human beings as human beings", and "whether there is any law that matches its true nature".

Rousseau wanted to use his work to "connect what the law allows to which interests that should be promoted, which prevents justice and interests from being separated." ${ }^{18}$ In order to do this, Rousseau divided his book into four parts (four books), in which part 1 discussed the transition of human society from natural status to civil status, about common will, and about the establishment of "social conventions"; part 2 mainly discussed legislative issues; part 3 focused on executive issues and part 4 discussed judicial issues and other guarantees of democracy.It is essential to pay attention to the core argument in part 1 of Rousseau's book:

"No one naturally has power on others. And strength alone does not create power; therefore only conventions can be the base for all reasonable power between people. "19

The establishment of conventions marks the transition of humankind from natural to civil status. With conventions, people lose the natural freedom and the limited rights to do what they want; but on the other hand people regain civil liberty and the right to own things that they have. With this transition, people give up the freedom that is limited by the individual's ability in exchange for much more freedom defined by the community's common will.

\footnotetext{
${ }^{18}$ Rousseau (1992), 28.

${ }^{19}$ Rousseau (1992), 35.
} 
When all members of society join the conventions, common will and public power are established. The state is the manifestation of that common will and power.

Public power is formed because the people join the conventions, thus the people are the holders of public power and public power cannot be divided either mechanically or casually like magic tricks. The people's common will also needs to be guaranteed; and when a common will is the true common will, then it is always good. ${ }^{20}$ Rousseau wrote: "If the people are informed properly, when they discuss problems, although there is no private interaction, or they have many minor differences in their opinions, the discussion still leads to the common will, the result is always good." He argued that all the plots of private individuals to turn private will into common will, even if that was able to cover everything, in reality still destroy the common will. However, only conventions and common will are not enough. Rousseau thought that:

"With social conventions, we make the political body exist and give it a life. We have to use the legislative activity to give the political body movement and will."21

But what are laws? According to Rousseau, laws are regulations of the common will and the citizens who follow laws have to be the ones who make the laws. That is the common principle, but in order to have harmony between the common and the private, between the body and the parts, there is a need for lawmakers. The law is the manifestation of the common will, so "legislation is the pinnacle of the perfection that collective strength can achieve", and legislators, in all aspects, have to be "the outstanding persons in the country." 22 Rousseau discussed the characteristics of lawmakers among which knowledge is of great importance, and the knowledge of lawmakers has to be outstanding, "to see clearly people's desires without giving preference to a certain desire." ${ }^{3}$ Rousseau also indicated that the purpose of the legal system is freedom and equality. He also distinguished four types of law,; "political law" that governs the relationship between the common and the private, "civil law" that governs the relationship among individuals, "criminal law" that governs the relationship between the citizens and the law, and "customary law" or "people’s opin-

\footnotetext{
${ }^{20}$ Rousseau (1992), 58.

${ }^{21}$ Rousseau (1992), 67.

${ }^{22}$ Rousseau (1992), 72.

${ }^{23}$ Rousseau (1992), 71.
} 
ions" that are not engraved on rocks or bronze but in people's minds, and which creates the nation's true constitution.

In part 2 Rousseau discusses the government or the executive body. If the legislative body is the highest organ of state power, then the government, according to Rousseau, is the intermediary body between the people and that highest organ. The legislative power belongs to the people, and can belong to it alone, while the executive power cannot belong to the generality. Members of the executive body cannot be involved in legislation. The function of the executive body is to implement tasks assigned by the legislative body, and the legislative body is able to take back, edit, and limit the power of the executive body. The existence of the executive body is essential, because if the legislative agency wants to perform an executive function, or the people do not follow the law (because there is no executive authority and the legislative body does not have an executive function), the country will be in chaos. Rousseau argued that there are three forms of government,

- democratic (the legislative body assigns the duty of managing the government to the people or the majority of people),

- aristocratic (the government is controlled by a small group), and

- monarchical (there is only one supreme judge).

There is also the mixedtype of government. Each form of government suits a specific type of nation. There is no absolutely good form or government. A good government is the government that educates the population, and vice versa. In order to prevent the government from seizing absolute power, the officials are only civil servants. The people are able to promote or dismiss them, and they have no choice but to follow. The people implement the above power through the people's conference (or congress).

Regarding the judicial body, Rousseau thought that this is a special organization which is not part of any other section; it "puts each section in the right position, serves as the connection and intermediary factor between the government and the people, or between the government and the highest organ of state power, or between all those three parties when necessary." ${ }^{24}$ It is "the most sacred organization" and most highly appreciated because it protects the law. The function of the judicial court is to announce public opinion, not to judge public opinion. "If the court deviates from that function, all of its deci-

${ }^{24}$ Rousseau (1992), 174. 
sions will become absurd and will have no effect." 25 The judicial body has to be separated from other organs of state power. "The judicial body will exceed its authority once it takes possession of executive power, which it is supposed to monitor. The judicial body also misuses its power if it issues laws, which it supposes to protect." 26 In order to prevent the judicial body from being corrupted, there is a need to determine a proper duration for it. This duration should not be too long so that the abuse of judicial power cannot take shape.

With the above opinions, Rousseau made distinctive contributions to the thoughts on the separation of powers. While Locke focused on the sovereignty of the people without discussing enough about the structure or the state system based on the spirit of separation of powers, and Montesquieu discussed in depth the structure of the state system without really focusing on the matter that the supreme holder of power is the people; Rousseau broke through both of the above limits by interpreting strength, right, power, conventions, and the manifestation of the position of the people as the holder of power in the structure of separation of powers. Rousseau's thinking on the separation of powers is profoundly dialectical. He himself did make the separation of powers concept a comprehensive theory.

\section{Conclusion}

It can be seen that the thoughts on the separation of powers of John Locke, Charles-Louis de Secondat de Montesquieu and Jean-Jacques Rousseau - three outstanding representatives of modern Western political thinkers - contain many profound values. Pervading all their thoughts is a noble goal: to protect human rights, to protect the supreme sovereignty of the people. That goal is manifested differently in the works of each of these thinkers, in rules to organize the state system and principles to operate state power. In this aspect, the common spirit that emerges - which is also a value that needs to be researched and applied - is to guarantee that the state system and state power are truly the people's tools to prevent the abuse of state power, or to prevent one part of state power from gaining the ability to control and govern other powers unrea-

\footnotetext{
${ }^{25}$ Rousseau (1992), 181.

${ }^{26}$ Rousseau (1992), 175.
} 
sonably. All of those do harm to the people and prevent them from being the supreme holder of all power in the society. It is evident that this is the opinion of using power to control power - the principle to internally control state power. Obviously, there are historical limits in these thinkers' opinions, and especially if we approach from the standpoint of Marxist politics, the inability to realize relations of interests, especially class interests, a key form of interest that plays a basic role in all political relationships, the substantiality and feasibility of the separation of powers principle is lacking a solid base, both in theoretical and practical terms.

\section{References}

Academy of Journalism and Communication, Faculty of Politics (ed.) (2005): Political Institutions in the World Today. Hanoi.

Chu Duong (2005): State Institutions in Different Countries in the World. Hanoi.

Ellis, William (ed.) (1985): The Politics of Aristotle or a Treatise on Government. London.

Ho Van Thong (1998): The Political Systems of Developed Capitalist Countries Today. Hanoi.

Locke, John (2007): The Second Treatise on Government. Hanoi.

Montesquieu, Charles-Louis de Secondat de (1996): The Spirit of the Laws (Vietnamese translation). Hanoi.

Nguyen Canh Binh (2013): How the Constitution of the USA was Made. Hanoi.

Nguyen Thi Hoi (2005): The Principle of Separation of Powers and the Organization of State Systems in Several Countries. Hanoi.

Nguyen Van Huyen (ed.) (2007): Political Systems of England, France, the USA. Hanoi.

Rousseau, Jean-Jacques (1992): The Social Contract. Ho Chi Minh City.

The Institute of Legal Science (ed.) (2005): Political Institutions and State Systems of Several Countries in the World. Hanoi.

Vu Hong Anh (1997): Organization and Operation of the Governments of Several Countries in the World. Hanoi. 